\title{
A CONTROLLED TRIAL OF INTRAVENOUS IMMUNE GLOBULIN FOR THE PREVENTION OF SERIOUS BACTERIAL INFECTIONS IN CHILDREN RECEIVING ZIDOVUDINE FOR ADVANCED HUMAN IMMUNODEFICIENCY VIRUS INFECTION
}

\author{
Stephen A. Spector, M.D., Richard D. Gelber, Ph.D., Nuala McGrath, M.S., \\ Diane Wara, M.D., Asher Barzilai, M.D., Elaine Abrams, M.D., Yvonne J. Bryson, M.D., \\ Wayne M. Dankner, M.D., Robert A. Livingston, M.D., Edward M. Gonnor, M.D., \\ and the Pediatric AIDS Clinical Trials Group*
}

\begin{abstract}
Background. Serious bacterial infections are common in children infected with the human immunodeficiency virus (HIV). Studies performed before zidovudine became standard therapy found that intravenous immune globulin decreases the number of serious bacterial infections in these children. We designed a multicenter study to evaluate the efficacy of intravenous immune globulin in children with advanced HIV infection who were receiving zidovudine.

Methods. In a double-blind trial 255 children between 3 months and 12 years of age who had the acquired immunodeficiency syndrome (AIDS) or AIDS-related complex were randomly assigned to receive either intravenous immune globulin (400 mg per kilogram of body weight) $(n=129)$ or placebo (0.1 percent albumin) $(n=126)$ every 28 days. All children received $180 \mathrm{mg}$ of zidovudine per square meter of body-surface area orally four times daily. Treatment assignment was stratified according to whether the patients had a history of one or more serious bacterial infections, had previously been treated with zidovudine, or were currently receiving prophylaxis with trimethoprim-sulfamethoxazole. The median length of follow-up was 30.6 months.
\end{abstract}

Results. The estimated two-year rates of serious bac-

$\mathrm{H}$ UMAN immunodeficiency virus (HIV) infection of adults and children results in severe dysfunction of $\mathrm{B}$ cells and $\mathrm{T}$ cells. ${ }^{1-4}$ Whereas in adults opportunistic infections are the most common manifestations of HIV-related immune impairment, children frequently have recurrent serious bacterial infections with common encapsulated bacteria. ${ }^{5-7}$ The Centers for Disease Control and Prevention (CDC) case definition of pediatric acquired immunodeficiency syndrome (AIDS) includes recurrent serious bacterial infections as an indicator of immunologic impairment. ${ }^{8}$

Studies have suggested that intravenous immune globulin decreases the incidence of serious bacterial infections, and some have noted improved survival. ${ }^{9-13}$ However, most of these studies in HIV-infected children have been small and not well controlled. In a large randomized, placebo-controlled study con-

From the University of California, San Diego, La Jolla, Calif. (S.A.S., W.M.D.); the Harvard School of Public Health, Boston (R.D.G., N.M.); the University of California, San Francisco (D.W.); Mt. Sinai Hospital, New York (A.B.); Columbia University, New York (E.A.); UCLA, Los Angeles (Y.J.B.); Johns Hopkins University, Baltimore (R.A.L.); and the New Jersey Medical School, Newark (E.M.C.). Address reprint requests to Dr. Spector at the University of California, San Diego, 9500 Gilman Dr., La Jolla, CA 92093-0672.

Supported by the Pediatric AIDS Clinical Trials Group, the National Institute of Allergy and Infectious Diseases, the National Institute of Child Health and Human Development, and the General Clinical Research Centers Program, Division of Research Resources, National Institutes of Health.

*The members of the Pediatric AIDS Clinical Trials Group who participated in this study are listed in the Appendix. terial infections with confirmed pathogens were 16.9 percent for the immune globulin group and 24.3 percent for the placebo group (relative risk, $0.60 ; 95$ percent confidence interval, 0.35 to $1.04 ; P=0.07$ ). The treatment effect was seen primarily among the 174 children who were not receiving trimethoprim-sulfamethoxazole prophylaxis at entry; the estimated two-year rates of infection were 11.3 percent for the immune globulin group and 26.8 percent for the placebo group (relative risk, $0.45 ; 95$ percent confidence interval, 0.22 to $0.91 ; P=0.03$ ). For the 81 children who were receiving trimethoprim-sulfamethoxazole prophylaxis initially, the rates were 27.7 percent in the immune globulin group and 17.7 percent in the placebo group (relative risk, 1.26; 95 percent confidence interval, 0.44 to $3.66 ; P=0.67$ ). The two-year survival was similar in the two groups: 79.2 percent among immune globulin recipients and 75.4 percent among placebo recipients $(P=0.41)$.

Conclusions. In children with advanced HIV disease who are receiving zidovudine, intravenous immune globulin decreases the risk of serious bacterial infections. However, this benefit is apparent only in children who are not receiving trimethoprim-sulfamethoxazole as prophylaxis. (N Engl J Med 1994;331:1181-7.)

ducted by the Intravenous Immune Globulin Study Group of the National Institute of Child Health and Human Development (NICHHD), HIV-infected children with mild-to-moderate symptoms (CD4+ lymphocyte counts, $\geqslant 200$ per cubic millimeter) who received intravenous immune globulin had significantly fewer serious and minor bacterial infections and were hospitalized less frequently than children receiving placebo. ${ }^{14,15}$ There was no survival advantage. In addition, the study was conducted when zidovudine was not fully established as standard therapy for children with symptomatic HIV infection. Thus, the NICHHD trial was not designed to evaluate the efficacy of intravenous immune globulin in children with advanced HIV infection who are receiving zidovudine therapy. Because children with advanced HIV infection are at highest risk for the development of serious bacterial infections and most often receive zidovudine therapy, the current study was designed to evaluate the efficacy of intravenous immune globulin in children with AIDS and AIDS-related complex who are being treated with zidovudine.

\section{Methods}

\section{Study Design and Entry Criteria}

The study was a randomized, double-blind, placebo-controlled trial designed to evaluate intravenous immune globulin in children with advanced HIV infection who were receiving zidovudine. It was conducted at 30 clinical centers sponsored by the National 
Institute of Allergy and Infectious Diseases Pediatric AIDS Clinical Trials Group and the NICHHD.

Children between 3 months and 12 years of age identified as having AIDS (as defined by the CDC) or AIDS-related complex (as defined below) and laboratory-confirmed HIV infection were eligible for the study. ${ }^{8,16}$ Children with lymphoid interstitial pneumonitis were excluded from enrollment unless they required supplemental oxygen or corticosteroids or met other entry criteria. Children considered to have AIDS-related complex were required to meet at least two of three major criteria (failure to thrive, persistent or recurrent oral candidiasis, and a CD4+ lymphocyte count below 500 per cubic millimeter) within three weeks before entry into the study or one major criterion and one minor criterion (persisten diarrhea, lymphadenopathy, organomegaly, cardiomyopathy, nephropathy, recurrent herpes simplex or herpes zoster, and thrombocytopenia) within two months before entry. Children were excluded if they had known hypersensitivity to intravenous immune globulin, had an acute bacterial infection requiring treatment at entry, or had received within four weeks of entry antiretroviral therapy other than zidovudine or immunomodulating agents (including immune globulin), experimental drugs, or drugs known to cause prolonged neutropenia or nephrotoxic effects. Children were also excluded if they had any of the following within four weeks before the study began: a total bilirubin concentration that was more than 3 times the upper limit of normal, a serum aspartate aminotransferase concentration more than 10 times the upper limit of normal, an estimated creatinine clearance below $50 \mathrm{ml}$ per minute per $1.73 \mathrm{~m}^{2}$ of body-surface area or a serum creatinine concentration above $2 \mathrm{~g}$ per deciliter, an absolute neutrophil count below 1000 per cubic millimeter, hematocrit below 24 percent, or a platelet count below 75,000 per cubic millimeter (except for patients with HIV-associated thrombocytopenia, for whom thrombocytopenia was not a reason for exclusion).

The study patients were stratified at entry according to whether they had a history of one or more serious bacterial infections (defined as meningitis, bacteremia, pneumonia, osteomyelitis, septic arthritis, acute mastoiditis, acute sinusitis, and abscess of an internal organ) within two years before entry; had previously received zidovudine therapy; or were currently receiving trimethoprim-sulfamethoxazole prophylaxis against Pneumocystis carinii pneumonia.

Children could not receive any other antibiotics prophylactically except trimethoprim-sulfamethoxazole as prophylaxis against $P$. carinii pneumonia, in which case the recommended dosage regimen was $75 \mathrm{mg}$ of trimethoprim per square meter and $375 \mathrm{mg}$ of sulfamethoxazole per square meter given twice daily three times per week (on a Monday, Tuesday, Wednesday schedule). Children were permitted to receive trimethoprim-sulfamethoxazole prophylaxis on the basis of prevailing medical standards, which changed during the course of the study. During the first study year, October 27,1988 , to October 1, 1989, only children with a history of laboratory-documented $P$. carinii pneumonia were permitted to receive such prophylaxis. From October 1, 1989, to March 1, 1991, it was strongly recommended that children with AIDS or CD4+ lymphocyte counts below 500 per cubic millimeter receive prophylaxis. After March 1, 1991, the CDC guidelines for $P$. carinii pneumonia prophylaxis were followed. ${ }^{17}$

\section{Treatment Protocol}

The children were assigned in a double-blind fashion to receive either $400 \mathrm{mg}$ of intravenous immune globulin (Gamimune N, Cutter Biological, Miles Laboratories, Berkeley, Calif.) per kilogram of body weight every 28 days, or placebo ( 0.1 percent albumin without preservatives in 10 percent maltose). All children entering the study were treated with $180 \mathrm{mg}$ of zidovudine per square meter orally every six hours. The study protocol and informed-consent form were approved by each center's institutional review board. Written informed consent was obtained from a parent or legal guardian of each child. The children were seen every 28 days to receive the study drug or placebo and to be evaluated for intercurrent infections, medications, and hospitalizations.

\section{Definition of Outcomes}

The primary end points of the study were a reduction in the frequency of serious bacterial infections with pathogens whose identity was confirmed and a prolongation of survival. Other study end points included comparative tolerance of the two regimens, a reduction in the frequency of other bacterial infections, a reduction in the number of hospitalizations for acute care, and immunologic outcomes as defined by changes in CD4+ lymphocyte counts. Serious bacterial infections were classified by the study chairperson without knowledge of the treatment assignment. Serious bacterial infections with confirmed pathogens included meningitis, bacteremia, pneumonia, osteomyelitis, septic arthritis, and deep abscess. In addition, pneumonia documented on x-ray film but for which the pathogen was unknown and all cases of acute sinusitis regardless of whether the pathogen was known were included as serious bacterial infections in a secondary analysis of combined confirmed-pathogen and clinically diagnosed serious infections. All other bacterial infections, with or without confirmation of the pathogen involved, were considered nonserious bacterial infections.

\section{Statistical Analysis}

A study sample of 250 patients was selected to ensure an 80 percent power to detect an overall decrease of 15 percentage points in the rate of serious bacterial infections with confirmed pathogens at two years (rates of 25 percent in the placebo group and 10 percent in the immune globulin group) with a two-sided test and an alpha level of 0.05 . The data and safety monitoring board of the AIDS Clinical Trials Group reviewed the study on five occasions using an efficacy monitoring rule based on an O'Brien-Fleming use function. ${ }^{18,19}$ The study was completed as planned with 262 patients enrolled, of whom 255 were available for analyses.

The length of time to the first serious bacterial infection with a confirmed pathogen and all serious bacterial infections (with or without documented pathogens) was estimated with the KaplanMeier method, ${ }^{20}$ and standard errors were calculated with Greenwood's formula. ${ }^{21}$ Two-year event rates were used to summarize treatment results. Estimates of the relative risk of an event and $\mathbf{9 5}$ percent confidence intervals were calculated with Cox proportionalhazards regression models. ${ }^{22}$ Cox models were also used to investigate the role of prognostic factors and to evaluate possible interaction effects.

The rates of hospitalization, serious bacterial infections, and nonserious bacterial infections were expressed as the number of episodes per patient-year. Confidence intervals for the estimates of relative risk were calculated with a bootstrap method to handle multiple events in a single patient. ${ }^{23}$ For each patient slopes of $\log$ CD4 + lymphocyte counts over time were plotted, and a Wilcoxon statistic was used to test for treatment differences. Adjustments for age were made with age-related normal values and blocking according to base-line age in a two-way analysis of variance. All $P$ values were two-sided.

\section{Results}

\section{Study Population}

The study enrolled 262 children between October 27, 1988, and August 16, 1990. Two were ineligible for the study: one did not have HIV infection, and one did not meet the entry criteria. Five children never started treatment and had inadequate follow-up data for analysis. Thus, a total of 255 children were available for analyses. The mean length of follow-up was 25.5 months (median, 30.6).

The base-line characteristics of the 255 children are shown in Table 1. The median age of the study population was 2.5 years, and 43 percent of the children were under 2 years of age. Fifty-six percent of the children were boys, and 82 percent belonged to a minority racial or ethnic group. Seventy-one percent of the patients had CD4+ lymphocyte counts above 200 per cubic millimeter.

\section{Serious Bacterial Infections with Confirmed Pathogens}

Fifty-four children had at least one serious bacterial infection with a confirmed pathogen, 22 receiv- 
Table 1. Base-Line Characteristics of the Group as a Whole and According to Whether Trimethoprim-Sulfamethoxazole Prophylaxis Was Given Initially.*

\begin{tabular}{|c|c|c|c|c|c|c|c|c|c|}
\hline \multirow[t]{2}{*}{ Characteristic } & \multicolumn{3}{|c|}{ All Children } & \multicolumn{3}{|c|}{$\begin{array}{l}\text { CHILDREN WITHOUT INITIAL TMP-SMX } \\
\text { IMMUNE }\end{array}$} & \multicolumn{3}{|c|}{ CHILDREN WITH INITIAL TMP-SMX } \\
\hline & $\begin{array}{l}\text { TOTAL } \\
(N=255)\end{array}$ & $\begin{array}{l}\text { IMMUNE } \\
\text { GLOBULIN } \\
(\mathrm{N}=129)\end{array}$ & $\begin{array}{l}\text { PLACEBO } \\
(\mathrm{N}=126)\end{array}$ & $\begin{array}{c}\text { TOTAL } \\
(\mathrm{N}=174)\end{array}$ & $\begin{array}{l}\text { IMMUNE } \\
\text { GLOBULIN } \\
(\mathrm{N}=83)\end{array}$ & $\begin{array}{l}\text { PLACEBO } \\
(\mathrm{N}=91)\end{array}$ & $\begin{array}{c}\text { TOTAL } \\
(\mathrm{N}=81)\end{array}$ & $\begin{array}{l}\text { IMMUNE } \\
\text { GLOBULIN } \\
(\mathrm{N}=46)\end{array}$ & $\begin{array}{l}\text { PLACEBO } \\
(\mathrm{N}=35)\end{array}$ \\
\hline \multicolumn{10}{|l|}{ Age - yr } \\
\hline $\begin{array}{l}\text { Mean } \\
\text { Median }\end{array}$ & $\begin{array}{l}3.7 \\
2.5\end{array}$ & $\begin{array}{l}4.0 \\
3.3\end{array}$ & $\begin{array}{l}3.4 \\
2.0\end{array}$ & $\begin{array}{l}3.7 \\
2.5\end{array}$ & $\begin{array}{l}3.9 \\
3.4\end{array}$ & $\begin{array}{l}3.6 \\
2.1\end{array}$ & $\begin{array}{l}3.6 \\
2.5\end{array}$ & $\begin{array}{l}4.2 \\
3.7\end{array}$ & $\begin{array}{l}2.9 \\
1.8\end{array}$ \\
\hline Age $<2$ yr - no. $(\%)$ & $110(43)$ & $48(37)$ & $62(49)$ & $74(43)$ & $30(36)$ & $44(48)$ & $36(44)$ & $18(39)$ & $18(51)$ \\
\hline Initial TMP-SMX — no. (\%) & $81(32)$ & $46(36)$ & $35(28)$ & $\mathbf{0}$ & 0 & $\mathbf{0}$ & $81(100)$ & $46(100)$ & $35(100)$ \\
\hline Zidovudine before study entry - no. (\%) & $65(25)$ & $32(25)$ & $33(26)$ & $37(21)$ & $18(22)$ & $19(21)$ & $28(35)$ & $14(30)$ & $14(40)$ \\
\hline $\begin{array}{l}\text { History of serious bacterial infection - } \\
\text { no. }(\%)\end{array}$ & $113(44)$ & $59(46)$ & $54(43)$ & $79(45)$ & $37(45)$ & $42(46)$ & $34(42)$ & $22(48)$ & $12(34)$ \\
\hline Male sex - no. $(\%)$ & $142(56)$ & $64(50)$ & $78(62)$ & $101(58)$ & $43(52)$ & $58(64)$ & $41(51)$ & $21(46)$ & $20(57)$ \\
\hline
\end{tabular}

*TMP-SMX denotes trimethoprim-sulfamethoxazole prophylaxis.

ing immune globulin and 32 receiving placebo. The most common organisms identified were Streptococcus pneumoniae, other streptococci, and Staphylococcus aureus (Table 2). Gram-negative organisms were less common and were more evenly distributed between the two treatment groups. The main difference between the two groups was in the number of staphylococcal infections. In the placebo group there were 11 staphylococcal infections (7 due to $S$. aureus and 4 due to coagulase-negative staphylococcus), as compared with 3 in the immune globulin group (1 due to S. aureus and 2 due to coagulase-negative staphylococcus). These differences in staphylococcal infections were not associated with the use of central venous catheters. The two groups had similar numbers of streptococcal infections: 14 in the immune globulin group and 15 in the placebo group. Six children receiving both immune globulin and trimethoprim-sulfamethoxazole prophylaxis had a serious streptococcal infection.

The actuarial estimate of the percentage of patients with serious bacterial infections with confirmed pathogens at two years was 20.6 percent overall: 16.9 percent in the immune globulin group and 24.3 percent in the placebo group (Fig. 1). The estimated relative risk of such an infection (the ratio of the risk in the immune globulin group to the risk in the placebo group) was 0.60 (95 percent confidence interval, 0.35 to $1.04 ; \mathrm{P}=0.07$ by univariate logrank analysis).

\section{Prognostic Factors and Multivariate Analyses}

Treatment with immune globulin, age, sex, initial CD4+ lymphocyte count, a history of serious bacterial infection, prior zidovudine use, use of trimethoprimsulfamethoxazole prophylaxis at entry, and use of such prophylaxis during follow-up (as a time-varying covariate) were assessed in Cox proportional-hazards regression models to evaluate their effect on first confirmed serious bacterial infections. On the basis of a step-down procedure including only main effects, younger patients (those below two years of age) and patients with low CD4+ lymphocyte counts (below 200 per cubic millimeter at base line) had an increased risk of serious bacterial infection (Table 3). No other factors reached statistical significance.

Age, initial CD4+ lymphocyte count, and the interaction between immune globulin use and the use of trimethoprim-sulfamethoxazole prophylaxis at any time (the time-varying covariate) were significant factors in a second step-down procedure allowing all oneway interactions with treatment (Table 3). A model that included the use of trimethoprim-sulfamethoxazole prophylaxis at study entry also suggested an interaction with the use of immune globulin (Table 3). No other factors, including the interaction between immune globulin use and initial CD4+ lymphocyte count, were statistically significant. On the basis of the suggested interaction between the use of im-
Table 2. Bacterial Isolates from First Serious Bacterial Infections with Confirmed Pathogens.*

\begin{tabular}{|c|c|c|c|c|c|c|}
\hline \multirow[t]{2}{*}{ ORGANISM } & \multicolumn{2}{|c|}{ All Children } & \multicolumn{2}{|c|}{$\begin{array}{l}\text { CHILDREN WITHOUT } \\
\text { INITIAL TMP-SMX }\end{array}$} & \multicolumn{2}{|c|}{$\begin{array}{l}\text { CHILDREN WITH } \\
\text { INITIAL TMP-SMX }\end{array}$} \\
\hline & $\begin{array}{l}\text { IMMUNE } \\
\text { GLOBULIN } \\
(\mathrm{N}=129)\end{array}$ & $\begin{array}{l}\text { PLACEBO } \\
(\mathrm{N}=126)\end{array}$ & $\begin{array}{c}\text { IMMUNE } \\
\text { GLOBULIN } \\
(\mathrm{N}=83)\end{array}$ & $\begin{array}{l}\text { PLACEBO } \\
(\mathrm{N}=91)\end{array}$ & $\begin{array}{l}\text { IMMUNE } \\
\text { GLOBULIN } \\
(\mathrm{N}=46)\end{array}$ & $\begin{array}{l}\text { PLACEBO } \\
(\mathrm{N}=35)\end{array}$ \\
\hline $\begin{array}{l}\text { Total no. of serious bacterial infec- } \\
\text { tions with confirmed pathogens }\end{array}$ & $22 \dagger$ & $32 \ddagger$ & $11(3)$ & $26(3)$ & $11(9)$ & $6(5)$ \\
\hline Gram-positive bacteria & 17 & 26 & $9(3)$ & $20(3)$ & $8(6)$ & $6(5)$ \\
\hline Streptococcus pneumoniae & 9 & 11 & $4(2)$ & $10(1)$ & $5(3)$ & $1(1)$ \\
\hline Other streptococci & 5 & 4 & $2(1)$ & 3 & $3(3)$ & $1(1)$ \\
\hline Staphylococcus aureus & 1 & $7 \S$ & 1 & $5(2)$ & 0 & $2(1)$ \\
\hline Coagulase-negative staphylococcus & 2 & 4 & 2 & 2 & 0 & $2(2)$ \\
\hline Gram-negative bacteria & 5 & 6 & 2 & 6 & $3(3)$ & 0 \\
\hline Haemophilus influenzae & 0 & 2 & 0 & 2 & 0 & 0 \\
\hline Enterobacteriaceae & 3 & 2 & 1 & 2 & $2(2)$ & 0 \\
\hline Other & 2 & 2 & 19 & $2 \|$ & $1(1)^{* *}$ & 0 \\
\hline
\end{tabular}

*The values in parentheses are the numbers of patients who were receiving trimethoprim-sulfamethoxazole (TMP-SMX) prophylaxis at the time of the event.

tThere were 19 cases of bacteremia and 3 cases of pneumonia.

¥There were 27 cases of bacteremia, 2 cases of pneumonia, 2 cases of abscess, and 1 case of septic arthritis.

In one patient with a deep abscess, $S$. aureus and Clostridium perfringens were isolated.

TThe causative organism was Pseudomonas aeruginosa.

|The causative organism was $P$. aeruginosa in one case and Kingella kingae in one case.

**The causative organism was Acinetobacter calcoaceticus. 
mune globulin and the use of trimethoprim-sulfamethoxazole prophylaxis, we evaluated treatment effects separately according to the use of trimethoprim-sulfamethoxazole prophylaxis at study entry. The treatment effect was seen primarily among the 174 children who were not receiving such prophylaxis at study entry; the estimated two-year rates of infection were 11.3 percent for the immune globulin group and 26.8 percent for the placebo group (relative risk, $0.45 ; 95$ percent confidence interval, 0.22 to $0.91 ; \mathrm{P}=0.03$ ) (Fig. 2A). The two-year rates of infection among the 81 children who were receiving trimethoprim-sulfamethoxazole prophylaxis initially were 27.7 percent in the immune globulin group and 17.7 percent in the placebo group (relative risk, 1.26; 95 percent confidence interval, 0.44 to $3.66 ; \mathrm{P}=0.67$ ) (Fig. 2B).

\section{All Serious Bacterial Infections}

When all serious bacterial infections were evaluated, including confirmed-pathogen and radiologically confirmed pneumonias and sinusitis, the two-year event rate among children randomly assigned to immune globulin was 40.0 percent, as compared with 51.9 percent among children assigned to placebo (relative risk, 0.67; 95 percent confidence interval, 0.47 to $0.95 ; \mathrm{P}=0.03$, after adjustment for age and initial CD4+ lymphocyte count). Among children who were not receiving trimethoprim-sulfamethoxazole prophylaxis at entry the two-year event rates were 35.8 percent for those receiving immune globulin and 54.3 percent for those receiving placebo (relative risk, $0.59 ; 95$ percent confidence interval, 0.39 to $0.91 ; P=0.02)$. Among children who were receiving such prophylaxis at entry, the two-year rates were 48.0 percent and 45.2 percent, respectively (relative

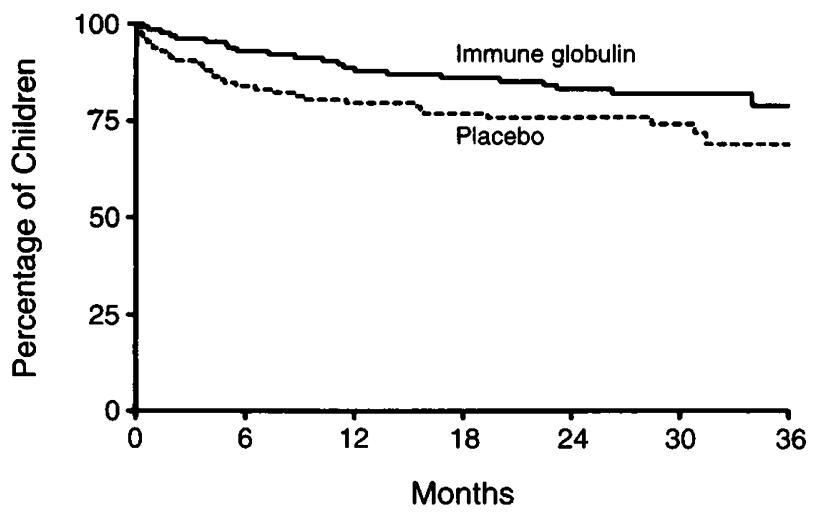

$\begin{array}{lcc} & \begin{array}{c}\text { Total } \\ \text { Events }\end{array} & \begin{array}{c}2-Y r \text { Event } \\ \text { Rate }(\%)\end{array} \\ \text { Immune globulin }(n=129) & 22 & 17 \pm 3 \\ \text { Placebo }(n=126) & 32 & 24 \pm 4\end{array}$

Figure 1. Kaplan-Meier Plot of the Time to a First Serious Bacterial Infection with a Confirmed Pathogen among Children Receiving Intravenous Immune Globulin or Placebo.

$P=0.07$ by univariate log-rank analysis. Plus - minus values are means $\pm S E$.
Table 3. Multivariate Analyses of Risk Factors and Treatment for First Serious Bacterial Infection with Confirmed Pathogens.*

\begin{tabular}{|c|c|c|c|}
\hline VARIABLE & $\begin{array}{l}\text { Relative } \\
\text { RISK }\end{array}$ & $95 \% \mathrm{Cl}$ & P Value \\
\hline \multicolumn{4}{|l|}{ Model without interaction terms } \\
\hline Treatment (immune globulin vs. placebo) & 0.65 & $0.37-1.12$ & 0.12 \\
\hline $\begin{array}{l}\text { CD4+ lymphocyte count }\left(<200 / \mathrm{mm}^{3} \text { vs. }\right. \\
\left.\geqslant 200 / \mathrm{mm}^{3}\right)\end{array}$ & 2.26 & $1.26-4.05$ & 0.006 \\
\hline Age $(<2$ yr vs. $\geqslant 2$ yr $)$ & 1.99 & $1.13-3.50$ & 0.02 \\
\hline \multicolumn{4}{|l|}{$\begin{array}{l}\text { Model with interaction term between immune } \\
\text { globulin use and use of TMP-SMX pro- } \\
\text { phylaxis (time-varying) } \dagger\end{array}$} \\
\hline Treatment (immune globulin vs. placebo) $\ddagger$ & 0.40 & $0.19-0.84$ & 0.02 \\
\hline $\begin{array}{l}\text { CD4+ lymphocyte count }\left(<200 / \mathrm{mm}^{3} \text { vs. }\right. \\
\left.\geqslant 200 / \mathrm{mm}^{3}\right)\end{array}$ & 2.22 & $1.23-3.99$ & 0.008 \\
\hline Age $(<2$ yr vs. $\geqslant 2$ yr $)$ & 2.11 & $1.19-3.72$ & 0.01 \\
\hline TMP-SMX use at any time (yes vs. no) $\S$ & 0.39 & $0.17-0.87$ & 0.02 \\
\hline $\begin{array}{l}\text { TMP-SMX use and treatment (TMP-SMX pro- } \\
\text { phylaxis and immune globulin vs. other) }\end{array}$ & 3.51 & $1.09-11.30$ & 0.04 \\
\hline \multicolumn{4}{|l|}{$\begin{array}{l}\text { Model with interaction term between immune } \\
\text { globulin use and use of TMP-SMX pro- } \\
\text { phylaxis at study entry }\end{array}$} \\
\hline Treatment (immune globulin vs. placebo) $\ddagger$ & 0.45 & $0.22-0.91$ & 0.03 \\
\hline $\begin{array}{l}\text { CD4+ lymphocyte count }\left(<200 / \mathrm{mm}^{3} \text { vs. }\right. \\
\left.\quad \geqslant 200 / \mathrm{mm}^{3}\right)\end{array}$ & 2.20 & $1.21-4.00$ & 0.01 \\
\hline Age $(<2$ yr vs. $\geqslant 2$ yr $)$ & 2.08 & $1.17-3.71$ & 0.01 \\
\hline TMP-SMX use at study entry (yes vs. no)§ & 0.57 & $0.23-1.40$ & 0.22 \\
\hline $\begin{array}{l}\text { TMP-SMX use and treatment (TMP-SMX pro- } \\
\text { phylaxis and immune globulin vs. other) }\end{array}$ & 3.12 & $0.91-10.62$ & 0.07 \\
\hline
\end{tabular}

${ }^{*} \mathrm{CI}$ denotes confidence interval, and TMP-SMX trimethoprim-sulfamethoxazole.

tA time-varying covariate is one whose value for an individual patient may change over time. The model estimates the instantaneous risk of serious bacterial infection according to the current value of this covariate rather than according to its value at study entry.

¥An effect of immune globulin treatment in the absence of TMP-SMX prophylaxis.

$\S$ An effect of TMP-SMX prophylaxis in the absence of immune globulin treatment.

risk, $0.80 ; 95$ percent confidence interval, 0.40 to $1.59 ; \mathrm{P}=0.53$ ).

\section{Nonserious Bacterial Infections}

Children receiving immune globulin had fewer nonserious bacterial infections than those receiving placebo (relative risk, $0.67 ; 95$ percent confidence interval, 0.51 to $0.84 ; \mathrm{P}=0.001)$. The number of nonserious bacterial infections per patient-year was 1.2 for the immune globulin group and 1.8 for the placebo group. Among children initially receiving trimethoprim-sulfamethoxazole prophylaxis, the number of nonserious bacterial infections in those given immune globulin was 1.2 per patient-year, as compared with 1.6 in those given placebo (relative risk, 0.73 ; 95 percent confidence interval, 0.48 to 1.10 ; $\mathrm{P}=0.13)$.

\section{Hospitalization for Acute Care}

Overall, children receiving immune globulin had a lower rate of hospitalization than children receiving placebo. The mean number of hospitalizations per patient-year was 0.86 for those receiving immune globulin, as compared with 1.23 for those receiving placebo (relative risk, $0.70 ; 95$ percent confidence interval, 0.50 to $0.93 ; \mathrm{P}=0.02$ ). Children in the immune globulin group who were not receiving trimethoprim-sulfamethoxazole prophylaxis at entry had 0.78 hospitalization per patient-year, as compared with a rate of 1.27 for similar patients in the placebo group (relative risk, $0.61 ; 95$ percent confidence interval, 0.41 to 0.89 ; $\mathbf{P}=0.01)$. Among children receiving trimethoprim- 


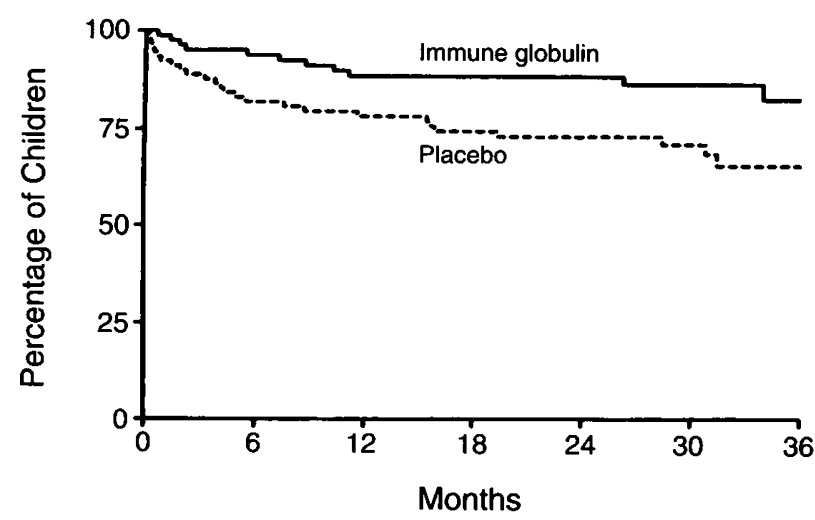

A

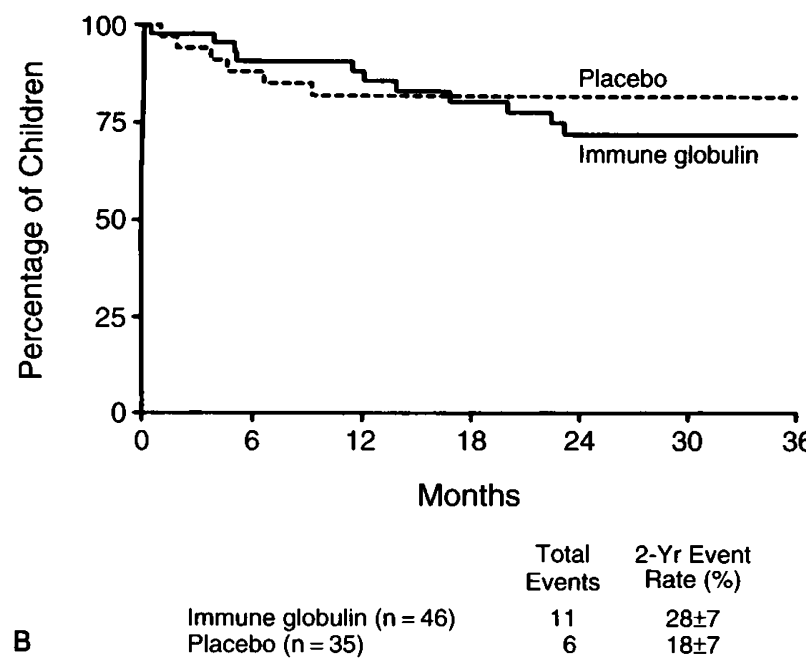

Figure 2. Kaplan-Meier Plots of the Time to a First Serious Bacterial Infection with a Confirmed Pathogen among Children Receiving Intravenous Immune Globulin or Placebo, According to Whether They Received Trimethoprim-Sulfamethoxazole Prophylaxis Initially.

Panel A shows the results for children who did not receive trimethoprim-sulfamethoxazole prophylaxis initially $(P=0.03$ by Cox analysis after adjustment for age and initial CD4+ lymphocyte count). Panel $B$ shows the results for children who received such prophylaxis initially ( $P=0.67$ by Cox analysis after adjustment for age and initial CD4+ lymphocyte count). Plus-minus values are means $\pm S E$.

sulfamethoxazole at entry, there were 1.02 hospitalizations per patient-year in the immune globulin group and 1.11 in the placebo group (relative risk, 0.90; 95 percent confidence interval, 0.50 to $1.63 ; \mathrm{P}=0.75$ ).

\section{Changes in CD4+ Lymphocyte Counts}

The median decreases in CD4+ lymphocyte counts were similar in the immune globulin group (1.07 percent per week) and the placebo group (0.92 percent per week; $P=0.40$ by the Wilcoxon test). Analyses adjusted for age with the use of age-related normal values $(P=0.28)$ and two-way analysis of variance
$(P=0.65)$ also found no statistically significant differences in CD4+ lymphocyte counts according to treatment.

\section{Survival}

Seventy of the 255 study patients had died by the end of the study. The estimated overall two-year survival was 77.3 percent -79.2 percent in the immune globulin group and 75.4 percent in the placebo group (relative risk, 0.82; 95 percent confidence interval, 0.51 to $1.62 ; P=0.41$ ). Even after adjustment for age and initial CD4+ lymphocyte count, survival was unaffected by the use of immune globulin (relative risk, 1.00; 95 percent confidence interval, 0.62 to $1.62 ; \mathrm{P}=1.0$ ). The use of immune globulin did not reduce the risk of death among children who were initially receiving trimethoprim-sulfamethoxazole prophylaxis (relative risk, 1.06; 95 percent confidence interval, 0.44 to $2.57 ; \mathrm{P}=0.90$ ) or among children who were not receiving such prophylaxis (relative risk, $0.88 ; 95$ percent confidence interval, 0.48 to $1.62 ; \mathrm{P}=0.68$ ).

\section{Adverse Reactions}

Adverse reactions associated with the infusion of the study drug or placebo were uncommon. Thirtyfour children reported adverse effects associated with infusion during the study, 18 receiving immune globulin and 16 receiving placebo. The reactions included fever, headache, nausea, glucosuria, rash, hypertension, neutropenia, and leukopenia. No adverse reaction was more common in the immune globulin group than in the placebo group. One child stopped taking intravenous immune globulin because of an allergic reaction to the infusion.

\section{Discussion}

This randomized, double-blind, placebo-controlled study of intravenous immune globulin in children with AIDS or AIDS-related complex who were receiving zidovudine was designed to detect a reduction in the risk of serious bacterial infection from 25 percent to 10 percent, a 60 percent reduction in the probability of the event. We believed that a large effect would be required to justify the routine use of immune globulin, given its expense, the need for monthly intravenous access, and our hypothesis that overall survival would not be affected. Within the preestablished criteria for efficacy, this study shows a moderate reduction in serious bacterial infections with confirmed pathogens with the use of immune globulin. However, the evidence also suggests an interaction between the effect of immune globulin and the use of trimethoprim-sulfamethoxazole prophylaxis. The benefit of immune globulin was seen primarily in children who were not receiving such prophylaxis. Treatment with immune globulin did not reduce the rate of serious bacterial infections with confirmed pathogens among children who were receiving trimethoprim-sulfamethoxazole prophylaxis. Immune globulin therapy decreased the number of bacterial infections when all serious and 
nonserious infections were considered, as well as the number and duration (data not shown) of hospitalizations in children with advanced HIV disease. In each analysis, the effect was primarily in children who were not receiving trimethoprim-sulfamethoxazole prophylaxis.

There are several important differences between this study and the trial of intravenous immune globulin conducted by the NICHHD ${ }^{14,15}$ that may explain the differences in the findings. The NICHHD clinical trial was not designed to evaluate the benefits of intravenous immune globulin in children receiving zidovudine therapy. Thus, at the start of that study, no children were receiving zidovudine, and fewer than half the children received antiretroviral treatment at any time during the study. In the present study, however, all the children received zidovudine, and the apparent ability of immune globulin to slow the decline in GD4 + lymphocyte counts ${ }^{24}$ was not observed. In addition, the children in the current study had more advanced disease with lower CD4+ lymphocyte counts than the children in the previous clinical trial. Another important difference between the two trials was the extent to which trimethoprim-sulfamethoxazole prophylaxis for $P$. carinii pneumonia was used. Only 15 percent of the children enrolled in the NICHHD study received trimethoprim-sulfamethoxazole at entry, as compared with 32 percent in the current study. Furthermore, 66 percent of all participants received the drugs at some time during our study. The extensive use of trimethoprim-sulfamethoxazole appeared to obscure the apparently beneficial effects of immune globulin.

As well as being of limited benefit against bacterial infection in our study, immune globulin offered no significant improvement in survival. The NICHHD trial also failed to show any improvement in survival. Thus, neither study supports the use of intravenous immune globulin in $\mathrm{HIV}$-infected children if reduction in mortality is the primary objective.

The results of this trial should not be interpreted as indicating that no children infected with HIV should receive intravenous immune globulin. The two-year event rate for serious bacterial infections with confirmed pathogens was 20.2 percent for the entire cohort. Thus, children with symptomatic HIV infection remain at risk for bacterial infections despite antiretroviral therapy. Risk factors for serious bacterial infections were young age and low CD4+ lymphocyte counts; children with these factors are at highest risk for $P$. carinii pneumonia and may well be receiving trimethoprim-sulfamethoxazole prophylaxis. However, children with advanced HIV disease who are not receiving such prophylaxis may benefit from treatment with immune globulin. Antimicrobial prophylaxis with an oral antibiotic, particularly one with activity against gram-positive bacteria including $S$. pneumoniae and $S$. aureus, might decrease the number of serious bacterial infections. Further studies will be necessary to evaluate this possibility.
We are indebted to the children and parents who volunteered to participate in this study; to Bonnie Zimmer for assistance in the preparation of data for this manuscript; and to Dr. R. Schwartz and Cutter Biological, Miles Laboratories, for donating the intravenous immune globulin and placebo preparation for this study.

\section{Appendix}

The following members of the Pediatric AIDS Clinical Trials Group participated in this trial: Baylor University, Houston W.T. Shearer, M. Doyle, C.G. Hanson, and J. Laflen; Boston City Hospital, Boston - S.I. Pelton, E.R. Cooper, and A.M. Regan; Case Western Reserve University, Cleveland - P. Toltzis, M. Zucker, and M. Chance; Children's Memorial Hospital, Chicago - R. Yogev and E. Chadwick; Cincinnati Children's Hospital, Cincinnati - R.C. Baker and R. Siegel; Columbia University, New York - J. Pitt, A.A. Gershon, and N. Kanem; Emory University, Atlanta - S.R. Nesheim, A.J. Nahmias, H.L. Keyserling, and M.K. Sawyer; Milton S. Hershey Medical Center, Hershey, Pa. J. Dossett, M.E. Eyster, and L.J. Cubble; Johns Hopkins University, Baltimore - R. Yolken, J. Modlin, and P. Vink; Mt. Sinai Medical Center, New York - R. Warford, S. Heaton, D. Hodes, and H.S. Sacks; New Jersey Medical School, Newark G. McSherry, J. Oleske, J. Picardi, and N. Golabelli; New York Medical College, Valhalla - A. Gupta; New York University, New York - W. Borkowsky, S. Chandwani, M. Rigaud, and A. Kaul; Ohio State University, Columbus - M.T. Brady, J.A. Hunkler, and L.B. Crim; Schneider Children's Hospital, New Hyde Park, N.Y. - V.R. Bonagura and D.J. Valacer; St. Luke's-Roosevelt Hospital, New York - S. Bakshi, M.H. Grieco, J. Rivers, and G. McKinley; State University of New York, Brooklyn - S. Fikrig; Tulane University, New Orleans - R.B. Van Dyke and T. Alchediak; UCLA, Los Angeles - A. Deveikis, V. Wong, and J. Church; University of California, San Francisco - A. Dorenbaum, A. Petru, and D. Trebithick; University of Illinois, Chicago - K. Rich; University of Massachusetts, Worcester - S. Cheeseman, J.L. Sullivan, and K. Luzuriaga; University of Minnesota, Minneapolis G.R. Jones, B.K. Goodroad, and H.H. Balfour, Jr.; University of Puerto Rico, San Juan - C. Diaz, L. Lugo, L. Flores, and C. Rivera; University of Washington, Seattle - S.K. Burchett, K. Mohan, I. Foster, and L. Corey; and Washington University, St. Louis - G. Storch, L. Breuklander, and M. Royal.

\section{REFERENCES}

1. Lane HC, Fauci AS. Immunologic abnormalities in the acquired immunodeficiency syndrome. Annu Rev Immunol 1985;3:477-500.

2. Ammann AJ, Schiffman G, Abrams D, Volberding P, Ziegler J, Conant $M$ B-cell immunodeficiency in acquired immune deficiency syndrome. JAMA 1984;251:1447-9.

3. Clerici M, Stocks NI, Zajac RA, et al. Detection of three distinct patterns of T helper cell dysfunction in asymptomatic, human immunodeficiency virusseropositive patients: independence of CD4 + cell numbers and clinical staging. J Clin Invest 1989;84:1892-9.

4. Roilides E, Clerici M, DePalma L, Rubin M, Pizzo PA, Shearer GM. Helper T-cell responses in children infected with human immunodeficiency virus type 1. J Pediatr 1991;118:724-30.

5. Krasinski K, Borkowsky W, Bonk S, Lawrence R, Chandwani S. Bacterial infections in human immunodeficiency virus-infected children. Pediatr Infect Dis J 1988;7:323-8.

6. Bernstein LJ, Krieger BZ, Novick B, Sicklick MJ, Rubinstein A. Bacterial infection in the acquired immunodeficiency syndrome of children. Pediatr Infect Dis J 1985;4:472-5.

7. Roilides E, Marshall D, Venzon D, Butler K, Husson R, Pizzo PA. Bacterial infections in human immunodeficiency virus type 1-infected children: the impact of central venous catheters and antiretroviral agents. Pediatr Infect Dis J 1991;10:813-9.

8. Revision of the CDC surveillance case definition for acquired immunodeficiency syndrome. MMWR Morb Mortal Wkly Rep 1987;36:Suppl 1S:3S$15 \mathrm{~S}$.

9. Gupta A, Novick BE, Rubinstein A. Restoration of suppressor T-cell functions in children with AIDS following intravenous gamma globulin treatment. Am J Dis Child 1986;140:143-6.

10. Calvelli TA, Rubinstein A. Intravenous gamma-globulin in infant acquired immunodeficiency syndrome. Pediatr Infect Dis J 1986:5:Suppl:S207-S210.

11. Wood CC, McNamara JG, Schwarz DF, Merrill WW, Shapiro ED. Prevention of pneumococcal bacteremia in a child with acquired immunodeficiency syndrome-related complex. Pediatr Infect Dis J 1987;6:564-6. 
12. Hague RA, Yap PL, Mok JYQ, et al. Intravenous immunoglobulin in HIV infection: evidence for the efficacy of treatment. Arch Dis Child 1989;64: 1146-50.

13. Siegal FP, Oleske JM. Management of the acquired immune deficiency syndrome: is there a role for immune globulins? In: Morell A, Nydegger UE, eds. Clinical use of intravenous immunoglobulins: proceedings of a conference held at Interlaken, Sept. 15-18, 1985. London: Academic Press. 1986:373-84

14. The National Institute of Child Health and Human Development Intravenous Immunoglobulin Study Group. Intravenous immune globulin for the prevention of bacterial infections in children with symptomatic human immunodeficiency virus infection. N Engl J Med 1991;325:73-80.

15. Mofenson LM, Moye J Jr, Bethel J, Hirschhorn R, Jordan C, Nugent R. Prophylactic intravenous immunoglobulin in HIV-infected children with CD4 + counts of $0.20 \times 10^{9} / \mathrm{L}$ or more: effect on viral, opportunistic, and bacterial infections. JAMA 1992;268:483-8.

16. Classification system for human immunodeficiency virus (HIV) infection in children under 13 years of age. MMWR Morb Mortal Wkly Rep 1987;36: 225-36.
17. Guidelines for prophylaxis against Pneumocystis carinii pneumonia for children infected with human immunodeficiency virus. MMWR Morb Mortal Wkly Rep 1991;40(RR-2):1-13.

18. O'Brien PC, Fleming TR. A multiple testing procedure for clinical trials. Biometrics 1979;35:549-56.

19. Kim K, Tsiatis AA. Study duration for clinical trials with survival response and early stopping rule. Biometrics 1990;46:81-92.

20. Kaplan EL, Meier P. Nonparametric estimation from incomplete observations. J Am Stat Assoc 1958;53:457-81.

21. Greenwood M. The natural duration of cancer. Reports on public health and medical subjects no. 33. London: Her Majesty's Stationery Office, 1926:1-26.

22. Cox DR. Regression models and life-tables. J R Stat Soc [B] 1972;34:187220 .

23. Efron B. Bootstrap methods: another look at the jackknife. Ann Stat 1979;7:1-26.

24. Mofenson LM, Bethel J, Moye J Jr, Flyer P, Nugent R. Effect of intrave nous immunoglobulin (IVIG) on CD4 + lymphocyte decline in HIV-infected children in a clinical trial of IVIG infection prophylaxis. J Acquir Immune Defic Syndr 1993:6:1101-13.

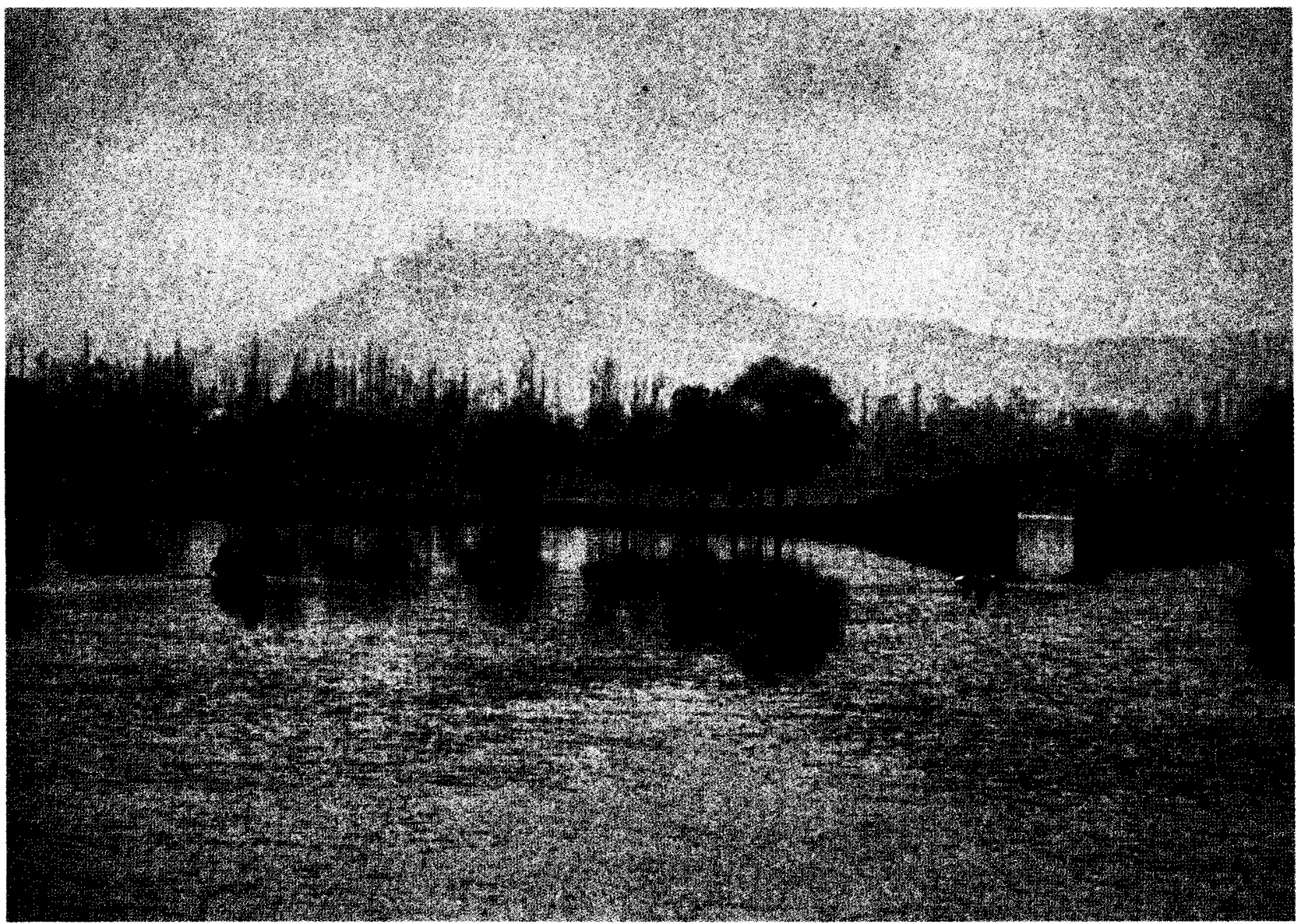

Timothy Holtz, M.D. 